\title{
The adaptation of nutrient oxidation to nutrient intake on a high-fat diet.
}

Citation for published version (APA):

Schrauwen, P., van Marken Lichtenbelt, W. D., Saris, W. H. M., \& Westerterp, K. R. (1997). The adaptation of nutrient oxidation to nutrient intake on a high-fat diet. Zeitschrift für Ernahrungswissenschaft, 4(306), 306-309. https://doi.org/10.1007/BF01617804

Document status and date:

Published: 01/01/1997

DOI:

10.1007/BF01617804

Document Version:

Publisher's PDF, also known as Version of record

\section{Please check the document version of this publication:}

- A submitted manuscript is the version of the article upon submission and before peer-review. There can be important differences between the submitted version and the official published version of record.

People interested in the research are advised to contact the author for the final version of the publication, or visit the DOI to the publisher's website.

- The final author version and the galley proof are versions of the publication after peer review.

- The final published version features the final layout of the paper including the volume, issue and page numbers.

Link to publication

\footnotetext{
General rights rights.

- You may freely distribute the URL identifying the publication in the public portal. please follow below link for the End User Agreement:

www.umlib.nl/taverne-license

Take down policy

If you believe that this document breaches copyright please contact us at:

repository@maastrichtuniversity.nl

providing details and we will investigate your claim.
}

Copyright and moral rights for the publications made accessible in the public portal are retained by the authors and/or other copyright owners and it is a condition of accessing publications that users recognise and abide by the legal requirements associated with these

- Users may download and print one copy of any publication from the public portal for the purpose of private study or research.

- You may not further distribute the material or use it for any profit-making activity or commercial gain

If the publication is distributed under the terms of Article $25 \mathrm{fa}$ of the Dutch Copyright Act, indicated by the "Taverne" license above, 
${ }^{*}$ P. Schrauwen

W. D. van Marken Lichtenbelt

W. H. M. Saris

K. R. Westerterp

\section{The adaptation of nutrient oxidation to nutrient intake on a high-fat diet}

Anpassung der Nährstoffoxidation an die Nährstoffaufnahme bei einer Hochfettdiät

Summary Intervention studies have shown that the adaptation of fat oxidation to fat intake, when changing the dietary fat content, is not abrupt. This study was conducted to measure the time course of adaptation of oxidation rates to increases in the fat content of the diet, when feeding subjects at energy balance. Twelve healthy, non-obese males and females (age: $26 \pm 2$, BMI: $21.4 \pm$ 0.5 , habitual fat intake: $29 \pm 1 \%$ energy) consumed a low-fat diet for 6 days (day 1-6) followed by a high-fat diet for 7 days (day 7-13). Days 5-9 and day 13 were spent in a respiration chamber. After adjusting energy intake to $24 \mathrm{~h}$ energy expenditure on day 5 , subjects were in energy balance (range -0.15 to $+0.23 \mathrm{~kJ} /$ day) on days 6-9 and day 13. Fat balance was zero on day 6 but became positive after changing to the high-fat diet $(1.06 \pm 0.15,0.75 \pm$ 0.15 , and $0.55 \pm 0.14 \mathrm{MJ} /$ day for days 7,8 , and 9 respectively, p. < 0.05 ), reaching a new balance on day 13,7 days afterwards. Thus, in case of energy balance, lean subjects are capable of adjusting fat oxidation to fat intake within 7 days, when dietary fat content is increased.

Zusammenfassung Untersuchungen haben gezeigt, daß die Anpassung der Fettoxidation an die Fettaufnahme, wenn Änderungen im Nahrungsfettgehalts vorgenommen werden, nicht abrupt geschieht. In dieser Untersuchung wurde der Zeitverlauf der Anpassung der Oxidationraten bei Vergrößerung des Nahrungsfettgehalts im Energiegleichgewicht gemessen. Zwölf gesunde, nicht übergewichtige männliche und weibliche Probanden (Alter: $26 \pm 2$, BMI: $21,4 \pm 0,5$, gewohnheitsmäßige Fettaufnahme: $29 \pm 1 \%$ Energie) erhielten über 6 Tage eine Niedrigfettdiät (Tag 16). Anschließend folgte eine 7tägige Hochfettdiät (Tag 7-13). Während der Tage 5-9 und 13

befanden sich die Probanden in einer Respirationskammer. Nach Einstellung der Energieaufnahme auf den 24h-Energiebedarf am Tag 5, waren die Probanden im Energiegleichgewicht $(-0,15 \pm 0,23$ $\mathrm{kJ} / \mathrm{d}$ ) während der Tage 6-9 und 13. Die Fettbilanz war am Tag 6 ausgeglichen, wurde aber positiv nach Umstellung auf Hochfettdiät $(1,06 \pm 0,15,0,75 \pm 0,15 ; 0,55 \pm 0,14$ $\mathrm{MJ} / \mathrm{d}$ für die Tage 7,8 und $9(\mathrm{p}<$ 0.05 ) und erreichte nach 7 Tagen ein neues Gleichgewicht (Tag 13). Schlußfolgernd kann gesagt werden, daß im Falle des Energiegleichgewichts, schlanke Personen in der Lage sind, die Fettoxidation innerhalb von $7 \mathrm{Ta}$ gen an die Fettaufnahme anzupassen, wenn der Nahrungsfettgehalt erhöht wird.

Key words Respiration chamber - substrate oxidation - respiratory quotient - high-fat diet

Schlüsselwörter Respirationskammer - Substratoxidation - respiratorischer Quotient - Hochfettdiät 


\section{Introduction}

For both protein and carbohydrate it has been shown that the rate of oxidation is well adjusted to intake (1). However, fat balance is poorly regulated and positive or negative energy balances (= energy intake minus energy expenditure) are accommodated by gains or losses of fat (2). Flatt (3) proposed a model, in which he states that, when the dietary fat content increases, fat oxidation can be raised by two mechanisms: 1) glycogen concentration can be maintained in a lower range, leading to lower glucose and insulin concentrations between meals, and hence higher fatty acid concentrations and higher rates of fat oxidation and/or 2) expansion of the adipose tissue mass which leads to enhanced fatty acid oxidation. In affluent societies with a surplus of food available, it is most likely that, on a high-fat diet, food intake will be increased to maintain filled glycogen stores. However, when energy intake is fixed, rapid shifts in substrate oxidation on a high-fat diet have been demonstrated (4). To our knowledge no studies have been reported which measured both acute and long term adaptation of substrate oxidation to alterations in diet composition. We, therefore, measured substrate oxidation on a habitual (low-fat) diet and subsequently the adaptation to a highfat diet during 7 days, while feeding subjects in energy balance. We hypothesized that complete adaptation to the changed fat content of the diet can occur within a few days.

\section{Subjects and methods}

Twelve healthy, non-obese males and females (age: $26 \pm 2$ yrs, BMI: $21.4 \pm 0.5 \mathrm{~kg} / \mathrm{m} 2$, habitual fat intake: 29 $\pm 1 \%$ energy) participated in this study. Subjects consumed a low-fat diet for days 1 to 6 , followed by a high-fat diet for days 7 to 13 . On days 5-9 and day 13 , subjects stayed in the respiration chamber. Low fat diets consisted of $30 \%$ energy as fat, $55 \%$ energy as carbohydrate, and $15 \%$ energy as protein. High-fat diets consisted of $60 \%$ energy as fat, $25 \%$ energy as carbohydrate, and $15 \%$ energy as protein. On the days spent at home, subjects were free to eat as much as they wanted. In the respiration chamber subjects were fed at energy balance.

Subjects weighed themselves every morning during their stay in the respiration chamber, after voiding and before eating and drinking. Measurements were done on a digital balance (Seca delta, model 707) accurate to 0.1 $\mathrm{kg}$. Oxygen consumption and carbon dioxide production was measured in a whole-room indirect calorimeter, which was described previously (5). Energy expenditure was calculated from $\mathrm{O}_{2}$ consumption and $\mathrm{CO}_{2}$ production according to the method of Weir (6). 24h energy expenditure (24h EE) and 24h RQ were calculated from 8:00 am to 8:00 am. Carbohydrate, fat and protein oxidation were calculated using $\mathrm{O}_{2}$ consumption, $\mathrm{CO}_{2}$ production, and urinary nitrogen losses with the equations of Brouwer (7). $24 \mathrm{~h}$ urine was collected from 8:00 am to 8:00 am. Samples were collected in containers with $10 \mathrm{ml} \mathrm{H}_{2} \mathrm{SO}_{4}$ to prevent nitrogen loss through evaporation; volume and nitrogen concentration were measured, the latter using a nitrogen analyzer (Heraeus, type CHN-O-Rapid).

\section{Results}

There were no significant differences in body weight between day 5 to 9 . A slight but significant decline in body weight of $0.62 \pm 0.21 \mathrm{~kg}$ was observed between day 9 and day $13(\mathrm{p}<0.05)$.

24h RQ and FQ are presented in Fig. 1. On day 5 and $6, \mathrm{RQ}$ and FQ were not significantly different. Between days 7 and 13,24h RQ declined significantly $(p<0.005)$, resulting in an equality of $R Q$ and $F Q$ on day 13.

On day 5 (first day in the respiration chamber ) a significantly negative energy balance was found. After individual adjusting of energy intake to energy requirement, energy balance was not significantly different from zero on days 6-9 and day 13 . Protein balance was not significantly different from zero during the measurement days (Fig. 2). Carbohydrate oxidation was not significantly different between days 5 and 6 . Carbohydrate oxidation declined significantly between day 6 and 13 $(p<0.001)$. This resulted in a significantly negative carbohydrate balance on days 7,8 , and 9 . On day 5 and 6 , as well as on day 13 carbohydrate balance was not significantly different from zero (Fig. 2). There were no significant differences in fat oxidation between day 5 and 6 . However fat oxidation raised significantly between day 6 and $13(\mathrm{p}<0.001)$. Fat balance was significantly

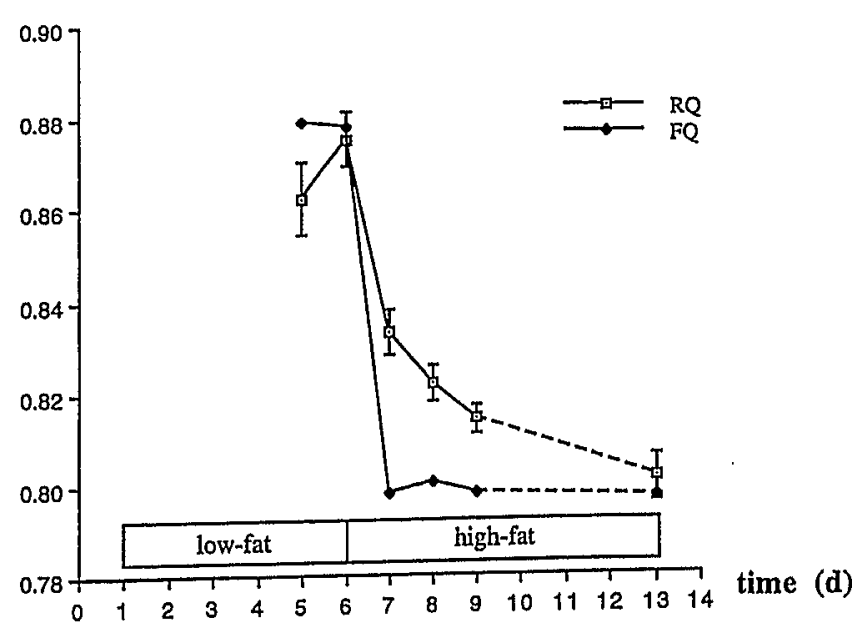

Fig. $124-\mathrm{h}$ respiratory quotients and $24-\mathrm{h}$ food quotients as meaFig. 1 24-h respiratory quotients and $24-4$ foys 5-9 and day 13 (mean \pm
sured in the respiration chamber for days s.e.m.) 


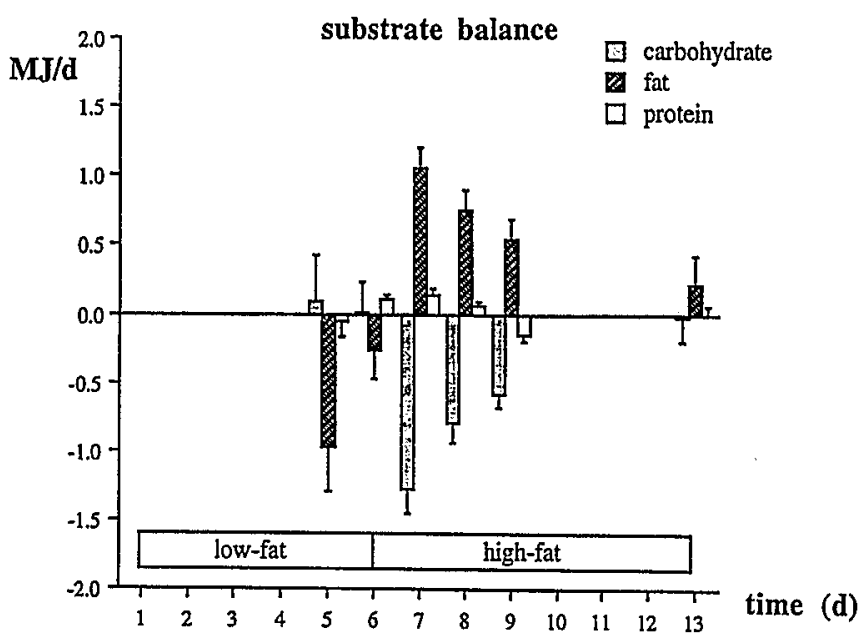

Fig. 2 Substrate balances for days 5-9 and day 13 as measured in the respiration chamber (mean \pm s.e.m.)

negative on day 5 , whereas on days 7,8 , and 9 a positive fat balance was reached. On day 6 as well as on day 13 fat balance was not significantly different from zero (Fig. 2).

\section{Discussion}

This study demonstrated that the body has a great capacity to adjust substrate oxidation to substrate intake on the long term for protein, carbohydrate, and fat. Earlier studies could not demonstrate such an adaptation to a highfat diet, probably because their subjects were not in energy balance. In contrast to other studies, in this experiment subjects were permanently in the chamber during the dietary switch and the subsequent days. During the stay in the respiration chamber $24 \mathrm{~h}$ energy expenditure was virtually constant, which made it possible to adjust energy intake to energy expenditure. Therefore, we were able to measure substrate oxidation with subjects being in energy balance during their stay in the respiration chamber. After three days on the high-fat diet RQ was shifted towards $F Q$, and seven days after the start of the high-fat diet (day 13) RQ and FQ were not significantly different. The results show that human subjects have a capacity to adjust RQ to $F Q$ in 7 days. Theoretically, the adaptation period under conditions of energy balance might be somewhat longer, because our data on body weight suggest that subjects were in a negative energy balance on the three days spent at home, which may have accelerated adaptation to the high fat diet.

In regulating substrate oxidation, the effect of glycogen content should be considered. According to Flatt's model (3) fat oxidation can be raised on high-fat diets by maintaining glycogen concentrations in a lower range. In our study we found a positive fat balance and a negative carbohydrate balance from days 7 to 9 . The negative carbohydrate balance (on average $-142 \mathrm{~g}$ between day 5 and 9) must have resulted in reduction of the glycogen stores, which was however not detectable in body weight. It, therefore seems that glycogen content of the body decreased until a new concentration was reached in which fat oxidation was sufficiently elevated to become in equilibrium with the elevated fat intake. However, it is also possible that fat oxidation was elevated because of increased enzymatic capacity for fat oxidation which occurred because of the exposure to the high-fat diet. Further studies are necessary to investigate the role of glycogen content in the regulation of fat oxidation in a situation of energy balance.

We demonstrated that normal-weight persons were able to reach substrate balance on a high-fat diet after one week. However, on the short term substrate balances could not be maintained. We can not conclude from these results whether obese or obese susceptible people would have the same capacity to maintain body weight on highfat diets. Ample evidence exists that (pre-, post-) obese people have a diminished fat oxidation capacity (8). It is also possible that in obese (susceptible) persons the time course of adjusting fat oxidation to increased fat intake is delayed (9). This will result in amounts of fat storage and glycogen mobilization, which are greater in obese (susceptible) people. Therefore, obesity might result from cumulative positive fat balances due to day to day fluctuations in fat intake as will occur in affluent societies, where food is always available ("party effect").

In conclusion, our results demonstrate that, in case of energy balance, lean subjects are capable of adjusting fat oxidation to fat intake within 7 days, when dietary fat content is increased.

\section{References}

1. Abbott WGH, Howard BV, Christin L, Freymond D, Lillioja S, Boyce VL, Anderson TE, Bogardus C, Ravussin E (1988) Short-term energy balance: relationship with protein, carbohydrate, and fat balances. Am J Physiol 255:E332-337

2. Schutz Y, Flatt JP, Jequier E (1989) Failure of dietary fat intake to promote fat oxidation: a factor favoring the development of obesity. Am J Clin Nutr 50:307-14

3. Flatt JP (1987) Dietary fat, carbohydrate balance, and weight maintenance: effects of exercise. Am J Clin Nutr 45:296-306

4. Hill JO, Peters JC, Reed GW, Schlundt DG, Sharp T, Greene HL (1991) Nu- trient balance in humans: effects of diet composition. Am $J$ Clin Nutr 54:10-7

5. Schoffelen PFM, Saris WHM, Westerterp KR, ten Hoor F (1984) Evalution of an automatic indirect calorimeter for measurement of energy balance in man, in Es AJHv (ed): Human Energy Metabolism: Physical Activity and 
Energy Expenditure Measurements in Epidemiological Research based upon Direct and Indirect Calorimetry, Wageningen, Euro-Nut, pp 51-54

6. Weir JBdV (1949) New methods for calculating metabolic rate with special reference to protein metabolism. J Physiol 109:1-9

7. Brouwer E (1957) On simple formulae for calculating the heat expenditure and the quantities of carbohydrate and fat oxidized in metabolism of men and animals, from gaseous exchange (oxygen intake and carbonic acid output) and urine-N. Acta Physiol Pharmacol Nederlandica 6:795-802

8. Blaak EE, van Baak MA, Kemerink GJ, Pakbiers MTW, Heidendal GAK, Saris WHM (1994) B-adrenergic stimulation of energy expenditure andforearm skeletal muscle metabolism in lean and obese men. Am J Physiol 267:E306-E315
9. Thomas CD, Peters JC, Reed GW, Abumrad NN, Sun M, Hill JO (1992) Nutrient balance and energy expenditure during ad libitum feeding of highfat and high-carbohydrate diets in humans. Am J Clin Nutr 55:934-42 